\title{
Impact of Traditional, Blended Learning, and Task Planning on the Learning of Resumptive Pronouns by Iranian EFL Learners
}

\author{
Bahar Rajabi \\ Department of Foreign Languages, Isfahan (Khorasgan) Branch, Islamic Azad University, Isfahan, Iran \\ baharrajabi.1988@yahoo.com \\ Mahmood Hashemian \\ Department of Foreign Languages, Isfahan (Khorasgan) Branch, Islamic Azad University, Isfahan, Iran \\ m72h@hotmail.com
}

\section{Doi:10.5901/mjss.2015.v6n4s1p39}

\section{Abstract}

Resumptive pronouns have been one of the most problematic issues in L2 teaching. The goal of this study was to see which of the 3 methods (i.e., traditional, blended learning, and task planning) is more successful to teach EFL learners to correctly use resumptive pronouns. Participants were 60 young intermediate L2 learners who were divided into 3 groups of 20 learners. All the participants were given a pretest to check their knowledge of resumptive pronouns, the result of which indicated their lack of knowledge of such pronouns. And, they were given a posttest at the end of the study to see the (probable) effect of the above methods on eradicating this problem. Participants were to submit 4 pieces of writing based on the topics in their lessons, the results of which indicated that comparing the 3 methods, task planning was more successful to help them to correctly use presumptive pronouns.

Keywords: Resumptive Pronouns, Task-Based Learning, Blended Learning, Traditional Method

\section{Introduction}

In the past, writing was not as important as other skills in L2 learning and it had been marginalized, but now it is viewed as an important function in second language learning (SLA). According to Harklau (2002), there should be more emphasis on writing in SLA research. She suggests that it is important to survey how L2 students learn to write in an L2 and also how student learn the $\mathrm{L} 2$ through writing.

Attempts have been made in order to develop theories in L2 writing which distinguish the differences as compared to writing in person's L1 (e.g., Grabe, 2001), such as the research done by Grabe (2001), in which he distinguished the cultural differences faced by L2 learners.

\section{Literature Review}

\subsection{Task-Based Language Teaching}

The arrival of TBLT is connected to what became famous as the Bangalore Project (Prabhu, 1987) which started in 1979 and completed in 1984. The word task here refers to the special kind of activities carried out in the classroom. Such activities are characterized by the emphasis put on meaning and the importance assigned to the process of doing things (how) vs. the winning role given to content (what) in the teaching procedure of that decade. The emphasis is on meaning to convey messages or the content and to associate of meaning and language so close to the real world. The only problem is that transmitting the meaning cannot be distinct from formal ways in which the meaning is conveyed (Nunan, 1989).

In the development of communicative language teaching (CLT), TBLT refers to usage of tasks as the main unit for planning and instructing for learning of L2 (Richards \& Rodgers, 2001, p. 223). According to Ellis (2003), the interest in this approach began in mid-1980s when SLA researchers concluded that making use of grammar-focused, communication-reduced teaching, and learning activities that were used in many L2 classes, did not result in acceptable 
results.

\subsection{Blended Learning}

Blended learning, as defined by Thorne (2003, p. 2), "blends online learning with more traditional methods of learning and development." As teachers begin to use blended learning in their classes, they face the possibilities and flexibility. This pedagogical approach should not be merely seen as a ratio of delivery model (face-to-face or online), but as "a fundamental redrawing of the instructional model, including a shift from lecture, to an increase in interaction that contains integrated assessment" (NACOL, 2008, p. 5).

As one scrutinizes the literature, he or she finds that the notion of blended learning is not new in SLA, and it has been used in L2 teaching and writing for a long time. As you can see, those L2 teachers who have been successful in their careers have made use of different methods-not just one specific one. The same is true for the successful learners who have fruitfully made use of different strategies for their $L 2$ learning. Besides, the most popular language institutes are using different means such as placement test, giving speeches, making their students use computers for some necessary activities, and so on.

\subsection{Relative Pronouns}

According to De Vies (2002), "relative pronouns are pronouns that undergo wh-movement" (148). In wh-movement language such as English, relative clauses involve wh-movement. This is a special constituent in the subordinate clause that is coreferential with a constituent in the main clause, and it is reformed in the form of a wh-word; afterwards, the reformed constituent moves to the Spec-CP. Relative pronoun is the name given to this wh-word or operator (Aartd \& Schils, 1995; Cook \& Newson, 1996; De Vries, 2002).

Thus, one can conclude that in English there is no resumptive pronoun in a simple restrictive RC, whereas Persian allows the existence of the resumptive pronoun in RC.

\section{Research Method}

\subsection{Participants}

The participants taking part in the present research consisted of $60 \mathrm{EFL}$ Iranian picked randomly from various English institutes in Esfahan. They were 15 to 19 years old. According to their level in the institutes and their scores from the last term, they were intermediate students.

\subsection{Materials}

The first test in this study was the OPT to check the homogeneity of the participant, and the second one was the researchers-made test. In order to make sure that the test was an acceptable one, the researcher calculated the reliability and validity prior to the study. The reliability of the test was calculated through KR-21 method, and it came out to be 0.82 which is an accepted result. Moreover, the researcher asked some university professors to judge the validity of the test, and it was approved by all. This teacher-made test was the main pretest and the posttest for the inferential analysis.

After conducting the study, that researchers-made test was again given to participants with some minor differences, making it almost impossible for the participants to use their prior knowledge.

\subsection{Procedure}

\subsubsection{Traditional Method}

This method was applied to the first group. Everything in this method was the same, and there was no change applied. The participants had a researchers-made test before the starting point of the term, and they had the researchers-made test again when term was finished. During this period, all the materials in the book were taught following this order: (1) teaching the point, (2) giving some extra example for the point, and (3) asking examples to do some exercises. 


\subsubsection{Task-Based Method}

For this group, the participants had the researchers-made test before piloting the study. Then, the researcher taught the participants some point about writing a paragraph (planning), and the relative elements (specially the resumptive pronouns). During the term, the participants were ought to hand in four pieces of writing based on specific subjects, and they had to do so according to planning and the lesson they had about the resumptive pronoun. At the end of the term, they were all given a researchers-made test again. The aim of this test was to analyze and check the effect of the teaching method. This method was applied to the second group.

\subsubsection{Blended Learning}

This method was applied to the third group. For this method, the researcher wanted the participants to answer the researchers-made test. The first and the third parts of teaching material were presented on the Weblog (http://learningenglishonline.mihanblog.com). There was a two-day deadline for the student to send their writings to the teacher's e-mail address. They had the second and the fourth material presented in the class, and again they had a twoday deadline to send the homework to their teacher for each one. After the term was finished, the participants were given the researchers-made test.

\subsection{Data Analysis}

The data from the pretest and the posttest given to the $L 2$ participants were subjected to statistical analyses to explore the probable effect of the treatment, applying matched $t$ test. For this study, there were three paired $t$ tests and four ANOVAs-one ANOVA for the placement test and three for the experiment.

\section{Results}

\subsection{Results of the Pretest}

The purpose of the pretest was to make certain that the BLG, TBG, and TMG were homogeneous at the outset of the study. One-way between-groups ANOVA was used to help achieve the purpose of the pretest. The results of the ANOVA analysis for the comparison of the BLG, TBG, and TMG are presented below in Table 4.1:

Table 4.1. Descriptive Statistics for Comparing the TMG, BLG, and TBG Pretest Scores

\begin{tabular}{ccccccccc}
\hline & \multirow{2}{*}{$N$} & \multirow{2}{*}{ Mean } & \multirow{2}{*}{ Std. Deviation } & \multirow{2}{*}{ Std. Error } & \multicolumn{2}{c}{ 95\% Confidence Interval for Mean } & \multirow{2}{*}{ Minimum } & \multirow{2}{*}{ Maximum } \\
\cline { 6 - 8 } & & & & & Lower Bound & Upper Bound & & \\
\hline TMG & 20 & 12.8000 & 1.57614 & .35244 & 12.0623 & 13.5377 & 10.00 & 16.00 \\
\hline BLG & 20 & 12.6500 & 2.03328 & .45465 & 11.6984 & 13.6016 & 10.00 & 17.00 \\
\hline TBG & 20 & 13.0500 & 1.57196 & .35150 & 12.3143 & 13.7857 & 11.00 & 16.00 \\
\hline Total & 60 & 12.8333 & 1.71895 & .22192 & 12.3893 & 13.2774 & 10.00 & 17.00 \\
\hline
\end{tabular}

Such descriptive statistics as mean and standard deviation are shown for the three groups in Table 4.1. The mean scores of the TMG $(M=12.80)$, BLG $(M=12.65)$, and TBG $(M=13.05)$ are not very much different.

\subsection{Results of the First Research Question}

The first research question of the study was whether blended learning affected Iranian L2 learners' learning of resumptive pronouns in their writing. A paired-samples $t$ test was run to capture any possible difference between the performances of the learners in the BLG on the pretest and the posttest (see Table 4.2): 
Table 4.2. Descriptive Statistics for Comparing the Pretest and Posttest Scores of the BLG

\begin{tabular}{cccccc}
\hline & & Mean & $N$ & Std. Deviation & Std. Error Mean \\
\hline \multirow{2}{*}{ BLG } & Pretest & 12.6500 & 20 & 2.03328 & .45465 \\
\cline { 2 - 6 } & Posttest & 15.7000 & 20 & 2.12999 & .47628 \\
\hline
\end{tabular}

In the BLG, the mean score on the pretest $(M=12.65)$ is substantially less than the mean score on the posttest $(M=$ 15.70). The conclusion could be that learning resumptive pronouns through blended instruction was effective.

\subsection{Results of the Second Research Question}

The second research question of the current study was formulated to investigate whether or not task planning improved the learning of resumptive pronouns by intermediate Iranian EFL learners. Like the analysis performed for the first research question, a paired samples $t$ test was conducted. Table 4.3 displays the descriptive statistics for this analysis:

Table 4.3. Descriptive Statistics for Comparing Pretest and Posttest Scores of the TBG

\begin{tabular}{cccccc}
\hline & & Mean & $N$ & Std. Deviation & Std. Error Mean \\
\hline TBG & Pretest & 13.0500 & 20 & 1.57196 & .35150 \\
\hline & Posttest & 17.7000 & 20 & 2.12999 & .47628 \\
\hline
\end{tabular}

It can be seen that in the TBG on the pretest, the mean score of the learners $(M=13.05)$ is enormously less than that of the posttest $(M=17.70)$. It could be concluded that there was a significant difference between the posttest scores of the learners in the TBG $(M=13.05, S D=1.57)$ and their posttest scores $(M=17.70, S D=2.12)$.

\subsection{Results of the Third Research Question}

The third research question of the study was designed to pose whether traditional classroom-based instruction could lead to the improvements in learning resumptive pronouns by intermediate Iranian EFL learners or not. Once again, a paired samples $t$ test was employed. Tables 4.4 depicts the analyses for this research question:

Table 4.4. Descriptive Statistics for Comparing the Pretest and Posttest Scores of the TMG

\begin{tabular}{cccccc}
\hline & & Mean & $N$ & Std. Deviation & Std. Error Mean \\
\hline TMG & Pretest & 12.8000 & 20 & 1.57614 & .35244 \\
\hline & Posttest & 12.4000 & 20 & 1.66702 & .37276 \\
\hline
\end{tabular}

The pretest mean score of the TMG was 12.80 , whereas the posttest mean score was 12.40 . This shows a slight regress on the part of the learners in this group. It could be inferred that the difference between the pretest and posttest scores of the TMG did not reach statistical significance.

\subsection{Results of the Fourth Research Question}

The last research question of the present study intended to find out whether or not method of instruction (i.e., blended, task planning, and traditional) had any effect on the learning of resumptive pronouns by intermediate Iranian EFL learners. A one-way between-groups ANOVA was used for this purpose (see Table 4.5):

Table 4.5. Descriptive Statistics for Comparing the TMG, BLG, and TBG Posttest Scores

\begin{tabular}{ccccccccc}
\hline & \multirow{2}{*}{$N$} & \multirow{2}{*}{ Mean } & \multirow{2}{*}{ Std. Deviation } & \multirow{2}{*}{ Std. Error } & \multicolumn{2}{c}{ 95\% Confidence Interval for Mean } & \multirow{2}{*}{ Minimum } & Maximum \\
\cline { 6 - 8 } & & & & & Lower Bound & Upper Bound & & \\
\hline TMG & 20 & 12.4000 & 1.66702 & .37276 & 11.6198 & 13.1802 & 9.00 & 16.00 \\
\hline BLG & 20 & 15.7000 & 2.12999 & .47628 & 14.7031 & 16.6969 & 11.00 & 20.00 \\
\hline TBG & 20 & 17.7000 & 2.12999 & .47628 & 16.7031 & 18.6969 & 13.00 & 22.00 \\
\hline Total & 60 & 15.2667 & 2.94507 & .38021 & 14.5059 & 16.0275 & 9.00 & 22.00 \\
\hline
\end{tabular}


The mean scores of the TMG $(M=12.400), \operatorname{BLG}(M=15.70)$, and TBG $(M=17.70)$ are not as homogeneous as they were on the pretest.

As is shown in Table 4.5, there was a statistically significant difference in the posttest scores for the TMG ( $M=$ $12.40, S D=1.66)$, the BLG $(M=15.70, S D=2.12)$, and the TBG $(M=17.70, S D=2.12)$. The conclusion being that the type of instruction brought about significant changes in the learning of resumptive pronouns by the learners.

The overall conclusion to be made from the results of the current study is that blended and task planning methods of instruction were effective to help the EFL learners learn resumptive pronouns, whereas the traditional method was not shown to be fruitful.

\section{Discussion}

One of these methods was the blended learning. Technology may provide a viable scaffold to support writing instruction for teachers and students (Oxford, 1990). One such form of educational technology is blended learning, which "blends online learning with more traditional methods of learning and development" (Thorne, 2003, p. 2). The use of technology has long been introduced as a complement for traditional writing classes (Chang et al., 2008; Fidaoui et al., 2010; Goldberg, Russell, \& Cook, 2003; Liou et al., 2011; Shang, 2007).

Task-based method was the other applied method, which recently has been known as an accepted and successful approach of teaching by L2 researchers and teachers. Based on what Ellis (2003) and Richards (2002) believed, TBLT is based on the implementation of tasks and procedures for producing effective results in an L2. In the development of communicative language teaching (CLT), TBLT refers to usage of tasks as the main unit for planning and instructing for learning of L2 (Richards \& Rodgers, 2001).

However, the results of the experiment showed that blended learning did actually affect the learning of resumptive pronouns by L2 learners, as the results of statistical analyses indicated. This conclusion is in line with previous experiment focusing on blended learning, such as Banados (2006), Barr et al. (2005), and Wold (2011), among others.

Besides blended learning, according to the second research question, task planning had a positive effect on the learning of resumptive pronoun as one can conclude based on the statistical outcomes presented in chapter 4 . In this regard, the study lends support to previous studies that have found positive effects of task planning on the learning of grammatical points (e.g., Brown, 2000; Celce-Murcia, Dornyei, \& Thurrell, 1997; Ellis, 2000; Fotos, 1993; Long, 1991; Skehan, 1996, to name a few).

The third research question was about the control group which was taught using the traditional method. According to the analyzed statistics presented in method, which is also in line with the third hypothesis, the traditional method was not as effective as the other methods applied in the present study.

According to the research questions, the purpose of the last question was to compare the results of the examined methods to see which one was more effective and useful. The results showed that there was a great gap between the results gained form the two experimental groups and the one control group (Traditional method group). By comparing the result from the study, one can conclude that TBLT was more effective than blended learning for the learning of resumptive pronouns. The second useful method was the blended learning, and the traditional method was not as effective as other methods used in the study.

\section{Conclusion}

The purpose of this research was to investigate the impact of traditional, blended, and task-based teaching methods on Iranian EFL learners' learning of resumptive pronouns. The present study was an attempt to compare the above three methods of teaching to see which one was the most effective for acquisition of resumptive pronoun among all.

The main result of the present study was the impact of task-based instruction on the learning of resumptive pronouns for the participants. The effect of this method was more than the other experimental group and the control groups. This is mainly because this method focused on tasks as the building blocks of its teaching/learning exercises and strategies (Nunan, 1989).

This study was in tune with recent studies such as Long (2002) in which he found that tasks focus on specific aspects of language within larger communication frameworks. This way, there would be no decontextualization for impeding the effective learning and the use of particularly focused part of the language in tasks.

Krashan (2002) mentioned a range of studies (Day \& Shapson, 1991; Harley, 1989; Lyster, 1994; Salaberry, 2000; Vanpatten \& Sanz, 1995) which claimed that the instruction which is under the TBLT is far more effective than the usual traditional instruction. 
According to Flyman-Mattsson (1999), one of the special characteristics of a task is that it focuses on different particular aspects of a language, no matter the feature is grammatical or it is related to vocabulary or discourse functions. She believed that tasks virtually embrace all aspects of a language without over emphasizing one on the other one. Thus, according to Flyman-Mattsson, one can make use of tasks for every all of the skills (i.e., speaking, listening, reading, and writing.)

It worth mentioning that whereas blended learning has a great effect on the learning of the resumptive pronouns, the effect of task-based method was even more noticeable in the posttest. The results imply that although the application of technology (i.e., the Internet and computer) resulted in a better writing performance, the interaction of the learners and teachers and the usage of tasks and brainstorming must be taken into account, too. In other words, it is the combination of traditional methodology and using tasks that result in better and more fruitful results.

To conclude, in the present study, blended online writing instruction was found to be the effective method for teaching problematic grammatical points to L2 learners. This finding is in agreement with other studies on blended learning in different disciplines.

Sitzmann et al. (2006) conducted a meta-analysis of 96 experimental studies on online and classroom instruction between 1996 and 2005. They concluded that blended learning optimizes the instructional advantages of online learning and classroom instruction.

In another study, Zhao et al. (2005) found that, there was no difference in overall effectiveness between online and face-to-face learning; they also noted that courses applying blended learning resulted in better learning outcomes than distance or face-to-face education alone.

In the same tune with this study, Kiliçkaya and Krajka (2010) studied the impact of online learning on English vocabulary knowledge of Turkish learners. The learners of online class were compared to learners of traditional classes. The results showed that the learners who received online teaching performed better than the other group. The results of the present study are in line with those of the previous studies. In yet another study, Kirkgöz (2011) investigated the speaking ability of learners and teachers of English using face-to-face instruction as well as technology, that is, video. At the end of the experiments, the students' oral communication skills changed significantly. The results of the present study are in line with the concluded results of Kirkoz.

The use of blended online learning itself does not suffice for guaranteeing the writing ability. There should be a teacher who organizes the materials. The teachers also are responsible for motivating, guiding, and giving feedback to students. The outcomes of this study facilitated the teachers' job to design and adapt language learning materials to improve the writing ability of the participants. Besides, as Allen (1983) points out, the current writing activities were criticized to be time consuming because they take much of the class time and the teacher's energy. If writing ability is integrated to other language skills and components like presenting through blended online instruction framework, it would help in saving L2 teachers' time and energy.

As revealed in the present study as well as other studies (Bahrani, 2011; Beatty, 2003; Roed, 2003; Vinther, 2011; Wiebe \& Kabata, 2010), CALL has many advantages over traditional classroom teaching and learning such as providing motivation and autonomy for learners, flexible learning, immediate and detailed feedback, reducing anxiety, and enhancing learners' involvement and participation.

According to Nunan (1987) and Williams (1998), in spite of the positive feedback from the students in successive years in the mentioned studies, it should be noted that computers can never replace the effect of teacher's presence, who is responsible for developing appropriate CALL programs and caring about students' progresses. Based on Richard (1997), teachers, by selecting learning activities, preparing students for new learning, presenting learning activities, asking questions, conducting drills, and checking students' understanding provide opportunities to practice new items, monitor learners' learning, give feedback on learners, and review and reteach when deemed necessary.

Analyzing the writing inferentially, one can easily find out that the writings of the learners participating in the both experimental groups were far better in shape, structure, and planning than the learners in the control group. But there was no significant difference between the experimental groups, and they were as good.

\section{Implications of the Study}

The application of blended online learning, from a pedagogical point of view, presents helpful insights to $L 2$ teachers, learners, and syllabus designers.

The results of this study can contribute to a better understanding of the effect of TBLT and blended learning on the learning of some problematic grammatical points. The results will be useful for $L 2$ teachers to prepare the most suitable teaching methods for the learners according to their specific conditions. 
The results have practical implications for materials developers to redesign the curriculum to include TBLT and blended learning classes or introduce online CALL materials into the curriculum, according to compatibility of the lesson and the learners because every method has its own benefits and limitations.

This study is also useful for the policy makers, since it provided a description of three upper-intermediate level writing classes. Other intensive English programs can determine similarities with their writing classes at the same proficiency level and apply the successful methods mentioned in the present study to achieve better outcomes.

\section{Suggestions for Further Research}

First, replication studies are crucial to confirm the findings of present research. Studies with more participants and larger groups would provide a clearer picture of the effects of different teaching methods on the learning of problematic grammatical points for young L2 learners (for the present study, the point was the resumptive pronoun). This may also be practical if this research is redone according to some other grammatical points.

Second, the study could be followed with plenty of other studies to confirm and strengthen the results and investigate the findings from different perspectives. One of the areas of study that can be encouraged is that of the inclusion of other varieties such as gender.

The third suggested point is to repeat the present study according to other proficiency levels such as advanced L2 learners. This would provide a more obvious picture of the results of the present study.

And finally, in addition to the effects of the applied methods on writing, the effects can be studied on other skills such as speaking or reading.

\section{References}

Aartd, F., \& Schils, E. (1995). The accessibility hierarchy and the contrastive analysis hypothesis. IRAL, 33(1), 47-63.

Allen, V. F. (1983). Techniques in teaching vocabulary. Oxford: Oxford University Press.

Bahrani, T. (2011). Computer assisted language learning; some aspects. Language in India, 11(9), 271-278.

Bañados, E. (2006). A blended-learning pedagogical model for teaching and learning EFL successfully through an online interactive multimedia environment. CALICO Journal, 23,533-550.

Barr, D., Leakey, J., \& Ranchoux, A. (2005). Told like it is! An evaluation of an integrated oral development project. Language Learning \& Technology, 9(3), 55-78.

Beatty, K. (2003). Teaching and researching computer-assisted language learning. New York: Longman.

Brown, H. D. (2000). Principles of language learning and teaching (4th ed.). Eaglewood Cliffs, NJ: Prentice Hall.

Celce-Murcia, M., Dornyei, Z., \& Thurrell, S. (1997). Direct approaches in L2 instruction: A turning point communication language teaching? TESOL Quarterly, 31, 141-152.

Chang, Y-C., Chang, J. S., Chen, H-J., \& Liou, H-C. (2008). An automatic collocation writing assistant for Taiwanese EFL learners: A case of corpus-based NLP technology. Computer Assisted Language Learning, 21(3), 283-299.

Cook, V.J., \& Newson, M. (1996). Chomsky's universal grammar: An introduction. Oxford: Blackwell.

Day, R., \& Shapson, S. (1991). Integrating formal approaches to language teaching in French immersion: An experimental study. Language Learning, 4, 25-58.

Ellis, R. (2003). Task-based language learning and teaching. Oxford: Oxford University Press.

Fidaoui, D., Bahous, R., \& Bacha, N. N. (2010). CALL in Lebanese elementary ESL writing classrooms. Computer Assisted Language Learning, 23(2), 151-168.

Flyman-Mattson, A. (1999). Students' communication behaviorism in foreign language classroom. Lund University Working Papers, 47, 39-57.

Fotos, S. S. (1993). Consciousness raising and noticing through focus on form: Grammar task performance versus formal instruction. Applied Linguistics, 14(14), 385-407.

Goldberg, A., Russell, M., \& Cook, A. (2003). The effect of computers on student writing: A meta-analysis of studies from 1992 to 2002. The Journal of Technology, Learning, and Assessment, 2(1), 1-52.

Grabe, W. (2001). Notes toward a theory of second language writing. In T. Silva \& P. K. Matsuda (Eds.), On second language writing (pp. 39-57). Mahwah, NJ: Lawrence Erlbaum Associates.

Harklau, L. (2002). The role of writing in classroom second language acquisition. Journal of Second Language Writing, 11(4), 329-50.

Harley, B. (1989). Functional grammar in French immersion: A classroom experiment. Applied Linguistics, 10, 331-359.

Kılıçkaya, F., \& Krajka, J. (2010). Comparative usefulness of online and traditional vocabulary learning. The Turkish Online Journal of Educational Technology, 9(2), 55-63.

Kirkgöz, Y. (2011). A blended learning study on implementing video recorded speaking tasks in task-based classroom instruction. Turkish Online Journal of Educational Technology, 10(4), 1-13.

Krashan, S. (2002). Explorations in language acquisition and use: The Taipei lectures. Taipei: Crane Publishing Company.

Liou, H.-C. Wang, S. H., \& Hung-Yeh, Y. (1992). Can grammatical CALL help EFL writing instruction? CALICO, 10(1), $23-44$. 
Long, M. H. (1988). A role for instruction in second language acquisition: Task-based language teaching. In K. Hyltenstam \& M. Pienemann (Eds.), Modeling and assessing second language development (pp. 77-99). Clevedon, Avon: Multilingual Matters.

Long, M. H. (1991). Focus on form: A design feature in language teaching methodology. In K. DeBot, R. Ginsberg, \& C. Kramsch (Eds.), Foreign language research in cross-cultural perspective (pp. 39-52). Amsterdam: John Benjamins.

Lyster, R. (1994). The effect of the functional-analytic teaching on aspects of French immersion students' sociolinguistic competence. Applied Linguistics, 15, 163-287.

NACOL. (2008). Fast facts about online learning. Retrieved January 15, 2013, from the World Wide Web: http:// www.NACOL.org

Nunan, D. (1987). Methodological issues in research. Adelaide: National Curriculum, Resource Center.

Nunan, D. (1989). Designing tasks for the communication classroom. New York: Cambridge University Press.

Oxford, R. L. (1990). Language learning strategies: What every teacher should know. Boston: Heinle \& Heinle.

Prabhu, N. (1987). Second language pedagogy. Oxford: Oxford University Press.

Richards, J. C., Platt, J., \& Platt, H. (1992). Longman dictionary of language teaching and applied linguistics. London: Longman.

Richard, J. C. (1997). Preparing language teachers for tomorrow's language classrooms. In G. M. Jacobs (Ed.), Language classrooms of tomorrow: Issues and responses (pp. 195-208). Singapore: SEAMEO Regional Language Center.

Richards, J. C., \& Rodgers, T. S. (2001). Approaches and methods in language teaching (2nd ed.). Cambridge: Cambridge University Press.

Richards, J. C. (2002). Accuracy and Fluency Revisited. In E. Hinkel \& S. Fotos, (Eds.), New perspectives on grammar teaching in second language classroom (pp. 1-15). Mahwah, NJ: Language Erlbaum Associates.

Roed, J. (2003). Language learner behavior in a virtual environment. Computer Assisted Language Learning, 16(2/3), $155-172$.

Salaberry, R. (2000). Pedagogical design of computer mediated communication tasks: Learning objectives and technological capabilities. Modern Language Journal, 84(1), 28-37.

Shang, H, F. (2007). Reading strategy use, self-efficacy and EFL reading comprehension. Asian EFL Journal, 12, 18-42.

Sitzmann, T., Kraiger, K., Stewart, D., \& Wisher, R. (2006). The comparative effectiveness of web-based and classroom instruction: A meta-analysis. Personnel Psychology, 59(3), 623-644.

Thorne, K. (2003). Blended learning: How to integrate online and traditional learning. London: Kogan Page.

Van Patten, B., \& Sanz, C. (1995). From input to output: Processing in instruction and communication tasks. In F. Beckman, D. highland, P. Lee, J. Milehow, \& R. Weber (Eds.), SLA theory and pedagogy (pp. 169-185). Hillsdale, NJ: Lawrence Erlbaum.

Vinther, J. (2011). Enhancing motivation with cultural narratives in computer-mediated communication. Computer Assisted Language Learning, 24(4), 337-352.

Vries, M., De. (2002). The syntax of relativization. The Netherlands: LOT.

Wiebe, G., \& Kabata, K. (2010). Students' and instructors' attitudes toward the use of CALL in foreign language teaching and learning. Computer Assisted Language Learning, 23(3), 221-234.

Williams, N. (1998). Educational multimedia: Where's the interaction. In M. Montreith (Ed.), IT for learning enhancement (pp. 153-170). Heereweg, Netherlands: Swets \& Zeitlinger.

Wold, K. A. (2011). Blending theories for instructional design: creating and implementing the structure, environment, experience, and people (SEEP) model. Computer Assisted Language Learning, 24(4), 371-382.

Zhao, M., Heinsch, F. A., Nemani, R. R., \& Running, S. W. (2005). Improvements of the MODIS terrestrial gross and net primary production global dataset. Remote Sensing of Environment, 95, 164-176. 